\title{
A Study on the Comprehension and Expression of Honorific System by Intellectual Disability Students
}

\author{
Wha Soo Kim¹, Ji Woo Lee', Su Jin Lee², Hu In Lee² \\ 'Department of Speech Language Pathology, Daegu University, Gyeongsan, Korea \\ ${ }^{2}$ Department of Speech Pathology, Graduate School of Daegu University, Gyeongsan, Korea
}

\author{
지적장애 학생의 높임법 이해 및 표현에 관한 연구 \\ 김화수 ${ }^{1} \cdot$ 이지우 ${ }^{1} \cdot$ 이수진 $^{2} \cdot$ 이후인 $^{2}$ \\ 대구대학교 언어치료학과', 대구대학교 일반대학원 재활과학과 언어치료전공
}

\begin{abstract}
Purpose: The purpose of this study was to identify differences in comprehension and expression of the honorific system for intellectual disability students (IDS) and confirm need for education. Methods: The subjects were 15 students with intellectual disability, 15 children with normal development matched for language age to the students with intellectual disability, and 15 ordinary adults matched for life age to the adults with intellectual disability. They were asked to examine 12 questions each on comprehension and expression honorific system individually. Results: First, as a result of the honorific system test, IDS's honorific system was increased as their language age $(10,11$, and 12 years) increased, and there were differences among three groups with different language age. Also, for the result of honorific types (e.g., subject, object, hearer honorifics) and level of difficulty in the honorific question types (e.g., above average, average, below average), there was a significant difference between the three groups. Second, an analysis of the percentage of IDS group's error responses to questions about the honorific system test showed that 'raising the name' and 'woo-ri/jeo-hui' questions had a high percentage of error answers. Conclusion: These results suggest that the IDS group is lower average to the honorific system than other groups. To use the honorific system is important to IDS group who starts social life soon because the honorific system is a communication method that respects the others. Therefore, it can be seen the honorific system education is necessary and suggests that IDS group needs to consider the types and difficulty levels in the education of honorific system.
\end{abstract}

Key Words: Students with intellectual disability, Honorific system, Subject honorific, Object honorific, Hearer honorific.

Received: August 14, 2019 / Revised: September 28, 2019 / Accepted: October 6, 2019

Correspondence: Huln Lee, Department of Speech Pathology, Graduate School of Daegu University, 201 Daegudae-ro, Jillyang-eup, Gyeongsan 38453, Korea

Tel: +82-63-465-9799 / Fax: +82-63-465-9719 / E-mail: gndls9799@naver.com

\section{INTRODUCTION}

성인이 된 발달장애인은 독립적인 생활과 자기 결정에 직면 한 과제와 마주하며 사회의 일원으로서 의사소통하며 살아가 야 한다. 우리나라에서 높임법이란 상대방과의 대화 시 중요한 언어적 요소로 작용하며, 예절과도 관련되어 있기 때문에 필수 적인 대화 기술이다. 높임법은 화자와 청자가 말하는 대상의 관

(c) This is an Open Access article distributed under the terms of the Creative Commons Attribution Non-Commercial License (https://creativecommons.org/licenses/by-nc/4.0) which permits unrestricted non-commercial use, distribution, and reproduction in any medium, provided the original work is properly cited.
계에 따라 높임 관계를 달리 표현할 수 있다. 높임법은 상대높 임법, 주체높임법, 객체높임법이 있다(Koo, 2006). 주체높임법 은 용언의 어간에 높임의 선어말 어미 '-시-'를 붙여 문장의 주 체를 높여 표현한다. 예로 '아버지께서 씨를 뿌리십니다., '어머 니는 지혜로운 분이십니다. 등이 있다. 객체높임법은 한 문장의 주어의 행위가 미치는 대상을 높여 표현한다. 예로 '보다', '주다, '말하다'에 대하여 '빕다', '드리다', '여쭈다’를 써서 표현하는 방 법과 조사 '-에게', '-한테'를 '-께”로 바꾸어 나타내는 방법이 있 다. 상대높임법이란 말하는 이가 말을 듣는 이를 자신과 비교 하여 높이거나 낮추는 방식이다. 문장의 종결 형식에 의해 종결 
어미를 선택함으로써 상대편을 높여 표현한다. '해라'체, '하게' 체, ‘하오'체, '하십시오'체, ‘해'체, ‘해요'체가 있다. 또한 높임법의 규범적인 사용은 문화적 관습, 사회적 요인(지위, 나이, 성별, 관 계, 역할 등)에 따라 정해지는 일반적인 높임법의 사용이다. 이 것은 대화 참여자들 간의 보이지 않는 합의에 의해 우선순위가 결정되며 대개는 이 규칙을 따른다(Kang, 2019).

한국어가 다른 언어와 구별되는 중요한 특성 중 하나는 "높임 법의 발달일 것이다. 대화 시 청자에 대한 판단을 잘못하여 상 대방이 기대하는 높임법 형식을 사용하지 않고 그것보다 낮은 단계의 형식을 사용하였을 때, 청자는 받아들이기가 어렵게 된 다. 그러나 상대방의 나이, 성, 지위, 그리고 상황 등에 알맞은 높임법 형식을 사용하였을 때 화자와 청자의 대화가 잘 진행되 고 친밀한 관계도 유지될 수 있다(Lee, 2002; Lee, 2019). $\operatorname{Kim}(2014)$ 은 국어의 높임법은 다른 사람을 존중하고 자신을 겸양하는 의식의 표현으로, 사회생활에서 원만한 인간관계 형 성과 효과적인 의사소통을 위해 반드시 필요한 언어 규범이라 고 설명한다. 또한 높임법을 지키지 않는다고 하여 의사 전달이 불가능하지는 않지만, 상대방으로부터 기대했던 정도의 언어 대우를 받지 못하는 경우에 불쾌함을 느끼게 되며, 이로 인하 여 사람들 사이의 크고 작은 갈등이 발생하기도 한다고 보고하 였다. $\operatorname{Kim}(2009)$ 은 우리말이 명시적 높임법 체계를 가진 언어 로 사회언어학적으로 강력한 구속력을 지니고 있기 때문에 높 임법의 체계를 바르게 이해하고 사용하는 것은 올바른 언어생 활과 원활한 사회적 인간관계를 위해 꼭 필요하다고 설명한다. 이처럼 높임법 사용은 사회 구성원으로 다른 사람과 원활한 관 계를 맺기 위해 필수적으로 사용되어야 하며, 대인관계나 다양 한 상황에서의 대화 시 문제가 발생하지 않기 위해서는 규범에 맞는 높임법 사용은 필수적이다.

그렇다면 높임법을 언제 어떻게 배우게 되는지를 살펴볼 필 요가 있다. 초등학교 교육 과정에 따르면 초등학교 3 4학년 문 법 영역에 '높임법을 알고 언어 예절에 맞게 사용한다.라고 목 표를 명시하고 있다(Ministry of Education, 2015). 또한 높임법 이 명시된 교과서의 내용을 학년별로 분석해 보면 〈초등학교 3학년 1학기-3단원 알맞은 높임 표현〉, 〈초등학교 3학년 2학 기-3단원 자신의 경험을 글로 써요〉, 〈초등학교 3학년 2학기5 단원 바르게 대화해요〉, 〈초등학교 4학년 1학기-3단원 느낌을 살려 말해요〉, 〈초등학교 4학년 1학기-6단원 회의를 해요〉, 〈초 등학교 4학년 1학기-9단원 자랑스러운 한글〉, 〈초등학교 4학년 2학기-3단원 바르고 공손하게〉 등의 영역에서 높임법 사용에 대해 제시하고 있다(Suh, 2019).

높임법 표현에 대한 교과서의 내용을 분석해 보면 초등학교 3 학년 1학기에는 가족의 어른, 선생님을 대상으로 높임법을 사 용한 문장 고르기, 초등학교 4학년 1학기는 공적인 회의 상황
에서 높임법 사용, 그리고 초등학교 4학년 2학기는 일상에서 만나는 이웃 어른들에게 높임법을 사용하는 사례로 구성되어 있다. 이러한 과정을 통해 본다면 높임법 사용을 배우는 단계 는 처음에는 이해 $\rightarrow$ 가족의 어른에게 높임법 사용 $\rightarrow$ 이웃 어 른들께 높임법 사용 또는 공적인 상황에서 높임법 사용의 단계 를 거쳐 학습이 된다고 볼 수 있다.

이렇게 교과서를 통해서 적정 연령에 교육을 실시하고 있기 는 하지만 보통은 일상생활을 통해서 주변 어른들이 하는 말 을 모방하거나 동화책 등을 통해서도 높임법이 학습된다고 볼 수 있다. 즉 일반 아동은 일상생활에서 청자와의 관계를 인지 하고, 대화 상황에서 자연스럽게 높임법을 습득하게 되고 학교 생활을 시작했을 때는 원활한 의사소통과 인간관계를 맺는 데 적절하게 높임법을 활용할 수 있게 된다. 그러나 지적장애 학생 들의 경우 청자와의 관계를 인지하고, 대화 상황에 맞는 적절한 높임법을 사용하는 데 제한을 보인다(Lee \& Heo, 2015).

지적장애인들이 높임법을 적절하게 사용하지 못하는 이유로 의사소통 능력(의미 능력, 구문 능력, 화용 능력)의 제한 때문 으로 보고 있다. 지적장애 학생의 기초 어휘 발달은 생활연령 을 기준으로 일반 학생에 비해 4세 이상 지체되며, 지적장애 학 생과 정신연령이 2 4세로 동일한 일반 아동의 기초 어휘 발달 을 비교했을 때는 지적장애 학생이 일반 학생보다 1.5 세 정도 의 지체된 발달을 보인다는 것이다(Choi, 2001). Kim(2002)에 의하면 지적장애 학생은 언어 규칙에 있어서도 문법 규칙을 사 용하기보다는 낱말 배열에 의존하는 경향이 있으며, 새로운 구 문 형태를 습득하는 데 학습 시간이 오래 걸리고 이미 학습한 구문 형태 역시 자발적으로 사용하는 데 매우 제한적이라고 하 였다(Kim et al, 2015; Kim et al, 2017; Kwon, 2015). 반면 구 문에서의 어려움이 아니라 지적장애인의 화용에 초점을 맞춘 연구도 존재한다. 이 연구들에서는 인식하고 이해하는 능력 및 청자로서 화자의 의도를 인식하고 이해하는 화용언어의 어려 움을 거론한다. 이와 같은 사회성의 문제는 화용적 언어 표현에 도 영향을 미치게 된다. 결국 선행연구들은 지적장애인이 어휘, 구문, 화용 능력이 일반 아동에 비해 떨어지기 때문에 높임법 표현이나 이해에 있어서 제한을 보인다는 것이다. 언어 능력의 제한으로 인해 높임법을 정확하게 사용하지 못한다면 사회적 상호작용과 원만한 인간관계를 갖는 데 실패하는 경험을 종종 갖게 되는 악순환의 고리로 진입하게 된다.

또 다른 연구에 따르면 지적장애인이 높임법 사용에 어려움 을 갖는 이유로 적응 행동의 제한으로 본다. American Association on Intellectual and Developmental Disabilities (Paul \& Courtenay, 2014)에 따르면 사회적 기술은 적응 행동 기술 중 하나로써 상호작용 기술, 사회적 책임감, 자존감, 사회적 문제 해결, 규칙을 따르고 법을 준수하는 능력을 말하며, 지적장애 
인은 이러한 적응 행동에서의 제한을 나타낸다고 제시하고 있 다. 많은 지적장애 성인들이 사회적 기능에서 결함을 지니고 있 으며, 그로 인해 정상적인 언어 기술을 가지고 있어도 다양한 상황에서 자신의 대화 능력을 이끌어 내는 것에 어려움을 나타 내고, 이러한 의사소통 기술의 부족은 사회적인 관계 형성의 어 려움으로 이어진다(Eom \& Kim, 2018).

$\operatorname{Kim}(2009)$ 은 높임법과 낮추는 말은 사회 구성원 간의 관계 를 규정짓는 하나의 언어적 수단이라고 지적하면서, 오랜 성장 기 동안 일상생활 속에서 자연스럽게 습득하여 습관화된다고 설명한다. 높임법을 사회에서 용인하는 수준에서 활용하지 못 하면 대인 간 관계에서 문제가 발생할 가능성이 높으며, 장애 학생 역시, 특히 고등학교 졸업 후 사회 구성원으로 활동하기 위해서는 사회에서 요구하는 관례로써 높임법을 의사소통 시 문제가 발생하지 않는 수준에서 활용할 수 있어야 한다는 것이 다. 성인이 된 지적장애인은 독립적인 생활과 문제 해결, 자기 결정 등의 직면한 과제에 마주하면서 직업을 얻고 사회의 일원 으로 의사소통하며 생을 살아가야 한다. 특히 직장에서의 의사 소통 장면에서는 구어 및 비구어의 사회적 의사소통과 함께 대 화 상대자에 따른 높임법 사용이 중요한 요소로 작용할 것이 다. 따라서 본 연구에서는 높임법에 대해서 교과 과정에서 수업 을 받고 있는 일반 초등학생과 어휘 능력 및 지적 능력 그리고 사회적 상호작용의 제한을 보이지만 청소년 말기에 해당하며 성년기 초기에 있으며 사회생활을 앞두고 있는 지적장애 성인 집단, 그리고 일반 성인 집단을 대상으로 높임법 이해 능력 및 표현 능력을 파악하여 높임법 교육 및 프로그램 개발에 필요한 기초 연구를 실시하고자 하였으며 연구 문제는 다음과 같다.

1) 집단 간(지적장애 학생 집단, 지적장애 집단과 언어연령을 일치시킨 일반 아동 집단, 지적장애 집단과 생활연령을 일 치시킨 일반 성인 집단) 높임법 이해 능력은 어떠한가?

(1) 언어연령(10세, 11세, 12세)에 따라 높임법 이해에 차이가 있는가?

(2) 높임법 유형(주체, 객체, 상대 높임법)에 따라 이해 능력에 차이가 있는가?

(3) 높임법 검사 문항 형식 난이도(상, 중, 하)에 따라 이해 능 력에 차이가 있는가?

2) 집단 간(지적장애 학생 집단, 지적장애 집단과 언어연령을 일치시킨 일반 아동 집단, 지적장애 집단과 생활연령을 일 치시킨 일반 성인 집단) 높임법 표현 능력은 어떠한가?

(1) 언어연령(10세, 11세, 12세)에 따라 높임법 표현에 차이가 있는가?

(2) 높임법 유형(주체, 객체, 상대 높임법)에 따라 표현 능력에 차이가 있는가?

(3) 높임법 검사 문항 형식 난이도(상, 중, 하)에 따라 표현 능
력에 차이가 있는가?

3) 지적장애 학생의 높임법 오류 유형은 어떠한가?

(1) 지적장애 성인 집단의 높임법 이해 문항 중 오류율은 어 떠한가?

(2) 지적장애 성인 집단의 높임법 표현 문항 중 오류율은 어 떠한가?

\section{MATERIALS AND METHODS}

\section{연구 대상}

본 연구의 대상은 총 세 집단으로, 1) 지적장애 학생 집단 15 명(평균 19;4세, 언어연령, 10세-5명, 11세-5명, 12세-5명), 2) 지 적장애 학생과 생활연령을 일치시킨 일반 성인 집단 15 명(언어연 령, 10세-5명, 11세-5명, 12세-5명), 3) 지적장애 학생과 언어연 령을 일치시킨 일반 아동 집단(언어연령, 10 세-5명, 11 세-5명, 12 세5 명)으로 전체 45명을 대상으로 하였다.

\section{지적장애 학생 집단}

연구 대상의 선정기준은 지적장애 학생 집단의 경우 경산시 평생교육원에 재학 중인 지적장애 학생들 가운데 첫째, 병원이 나 장애 관련 기관에서 지적장애 3급으로 진단받은 학생, 둘째, 수용·표현 어휘력 검사(Receptive \& Expressive Vocabulary Test, REVT) 결과 수용 어휘력의 언어연령이 10 12세 수준인 학생, 셋째, 이전에 높임법에 대한 표현·이해에 대한 프로그램 에 참여한 경험이 없었던 학생, 넷째, 중재에 영향을 미칠 수 있

Table 1. Characteristics of 15 participants with intellectual disability

\begin{tabular}{rccc}
\hline No. & $\begin{array}{c}\text { Chronological age } \\
\text { (yr;mo) }\end{array}$ & $\begin{array}{c}\text { Language age } \\
\text { (REVT-receptive) }\end{array}$ & Gender \\
\hline 1 & $18 ; 7$ & 10 & $\mathrm{M}$ \\
2 & $18 ; 7$ & 10 & $\mathrm{~F}$ \\
3 & $20 ; 10$ & 10 & $\mathrm{M}$ \\
4 & $19 ; 1$ & 10 & $\mathrm{M}$ \\
5 & $20 ; 7$ & 10 & $\mathrm{~F}$ \\
6 & $18 ; 11$ & 11 & $\mathrm{M}$ \\
7 & $18 ; 6$ & 11 & $\mathrm{~F}$ \\
8 & 20 & 11 & $\mathrm{~F}$ \\
9 & $19 ; 10$ & 11 & $\mathrm{~F}$ \\
10 & $19 ; 9$ & 11 & $\mathrm{M}$ \\
11 & $20 ; 5$ & 12 & $\mathrm{M}$ \\
12 & $19 ; 9$ & 12 & $\mathrm{M}$ \\
13 & $20 ; 3$ & 12 & $\mathrm{~F}$ \\
14 & 20 & 12 & $\mathrm{~F}$ \\
15 & $24 ; 2$ & 12 & $\mathrm{~F}$ \\
\hline
\end{tabular}

REVT: Receptive \& Expressive Vocabulary Test, M: male, F: female 
는 약물을 복용하지 않은 학생이었으며, 시각장애나 청각장애 와 같은 신체적 장애를 수반하지 않은 학생이었다. 지적장애 학 생의 특성은 Table 1 과 같다.

\section{지적장애 학생 집단과 생활연령을 일치시킨 일반 성인 집단}

1) 생활연령이 19;0 23;11세 이내.

2) 자가 보고에 의하여 언어, 시청각의 감각, 정서 및 행동, 그 리고 운동 발달의 문제가 없는 사람.

\section{지적장애 학생 집단과 언어연령을 일치시킨 일반 아동 집단}

1) 수용·표현 어휘력 검사(REVT) 실시 결과, 수용 어휘력의 등가 연령이 10;0 12;0세 수준.

2) 주 양육자, 교사, 또는 치료사의 보고에 의하여 언어, 시청 각의 감각, 정서 및 행동, 그리고 운동 발달의 문제가 없는 아동.

\section{검사 도구}

\section{수용·표현 어휘력 검사(REVT)}

일반 아동과 지적장애 학생의 언어연령을 평가하기 위해서 수용·표현 어휘력 검사(REVT) $(\mathrm{Kim}, 2009)$ 를 실시하여 수용 어휘 능력이 10세, 11 세, 12 세로 나타나는 지적장애 학생 15명 을 선정하였고, 지적장애 학생과 언어연령이 일치하는 일반 아 동 15 명을 선정하였다.

\section{높임법 검사(표현·이해 검사)}

본 연구는 지적장애 학생을 대상으로 높임법 표현 및 이해를 파악하는 것이 목적이다. 따라서 높임법 표현 및 이해 문항을 만들기 위해 “도대체 뭐라고 말하지?: 교과서 속 비슷한 말, 높 임말'(Suh et al., 2015), ‘우리말 표현력 활동책: 서로서로 통하 는 말-높임말과 대화 표현(Park \& Lee, 2017)과 Kang(2019), $\operatorname{Kim}(2009), \operatorname{Kim}(2014), W o n(2003)$ 의 연구에서 사용된 문항을 토대로 선택하였다. 특히 일생생활과 관련된 문항과 상황별 대 화의 내용을 수정하여 연구의 목적에 맞추어 수정 변경하였다. 분석 자료를 기초로 하여 높임법의 유형별로 주체, 객체, 상대 높임법으로 분류하였으며 검사 문항 형식 난이도에 따라서 상, 중, 하로 분류하였다. 분류한 결과에 따른 예시 문항은 Appen$\operatorname{dix} 1,2$ 와 같다.

높임법 검사 문항 형식 난이도 분류의 기준은 다음과 같다. 먼저 이해 검사에 있어서 검사 문항 형식 난이도 '상' 문항은 4 지선다의 문항이 4 개 모두 다른 대화로 이루어져 있으며 그중 에서 잘못된 문장을 고르는 문항이다. 검사 문항 형식 난이도 '중' 문항은 4지선다의 문항이 같은 주제로 이루어진 문장 중에 서 잘못된 문장을 고르는 문항이다. 검사 문항 형식 난이도 '하'
문항은 4지선다 문항 중 바르게 높임법을 사용한 문장을 고르 는 것으로 구성하였다. 표현 검사에서 검사 문항 형식 난이도 '상' 문항은 주어진 문장에서 잘못된 부분을 찾아 맞게 고치는 문항이다. 검사 문항 형식 난이도 ‘중’ 문항은 주어진 문장 중에 서 4지선다로 틀린 문제 번호를 고른 후 고쳐 쓰게 하였다. 검 사 문항 형식 난이도 '하' 문항은 밑줄 친 부분을 고쳐 쓰는 문 항으로 구성하였다. 또한 이렇게 구성한 문항에 대해서는 예비 검사를 통해 재점검 과정을 거쳤다.

본 검사는 외부와 단절되고 조용한 공간에서 대상자와 연구 자가 일대일로 마주 보고 앉은 상태에서 진행하였다. 각 대상자 에게 문제지에 있는 문제 유형 모두 같은 것이 아니기 때문에 문제를 꼼꼼하게 읽은 후 풀 수 있도록 설명하였다. 표현 연습 문항으로 '할아버지 밥 드세요.를 보여주고 이 문장에서 '밥’을 '진 지로 바꾼 후 고쳐 쓸 수 있도록 설명하였고, 이해 문항은 4지선 다 문제를 읽고 알맞은 혹은 틀린 문항 번호를 적도록 설명하였 다. 높임법 문제를 충분히 이해하고 풀 수 있도록 시간을 제한하 지 않았다.

\section{신뢰도 검사}

예비 검사를 통해서 표현 및 이해 각 24문항 중 높임법 검사 문항 형식 난이도 분류 기준에 적절하지 않은 문항, 정답을 혼 동할 수 있는 문항, 이해하는 데 어려움이 있는 문항 12 문항을 제외하고 최종적으로 높임법 이해 12 문항, 높임법 표현 12 문항 을 최종 선정하였다. 정답은 1점, 오답은 0점으로 채점하였다. 문항 적절성에 대해 검사하기 위해서 전문가 내용 타당도 검증 을 진행하였다. 내용 타당도는 언어치료 경력 10년 이상인 치료 사 4명이 타당도를 검증하였으며, 5점을 만점으로 하여 5점 척 도로 실시하였다. 내용 타당도 검증 결과 평균 4.3점 이상인 검 사 문항을 본 검사 문항으로 최종 결정하였다. 전반적인 높임법 이해·표현 검사 제작 과정은 Figure 1과 같다.

$$
\begin{aligned}
& \text { 1. Data collection (honorific relevant literature research) } \\
& \text { 2. Target person selection } \\
& \downarrow \\
& \text { 3. Development of preliminary inspection tools } \\
& \text { (comprehension · expression each of the } 24 \text { questions) } \\
& \downarrow \\
& \text { 4. Preliminary inspection } \\
& \text { 5. Main inspection } \\
& \text { (comprehension - expression each of the } 12 \text { questions) }
\end{aligned}
$$

Figure 1. Production order of honorific system comprehension and expression test. 


\section{자료 분석}

지적장애 학생 집단과 언어연령을 일치시킨 10세, 11세, 12세 일반 아동 집단, 생활연령을 일치시킨 성인 집단 간에 높임법 표현 능력과 이해 능력의 차이를 살펴보기 위해서 SPSS 22.0 (IBM Corp., Armonk, NY, USA)을 사용하였다. 각 집단의 검 사결과를 수치화하였으며, 비모수 통계 기법인 Kruskal-Wallis 와 일원배치 분산분석(one-way analysis of variance), Duncan 사후 검증을 실시하여 결과를 분석하였다. 자료 분석에서 비모수 Kruskal-Wallis 검증을 사용한 이유는 각 집단의 연령 별 평균 비교에서 집단별 인원이 각각 5명(10세-5명, 11 세-5명, 12 세 -5 명)으로 인원이 적기 때문에 비모수 검증을 실시하였 다. 또한 유형별(주체, 객체, 상대 높임법), 난이도(상, 중, 하)에 따른 결과를 알아보기 위해 일원변량분석을 실시하였다.

\section{RESULTS}

\section{높임법 이해 검사 결과}

두 집단(지적장애 학생 집단과 언어연령을 일치시킨 일반 아동 집단)의 언어 연령(10세, 11세, 12세)에 따른 높임법 이해 결과 언어연령 10 세|typically developing children (TD) $=5$ 명, intellectual disability students (IDS) $=5$ 명], 11 세 $(\mathrm{TD}=5$ 명, IDS = 5명), 12세(TD = 5명, IDS = 5명)의 높임법 이해 능력을 검사한 결과는 Table 2 와 같다.

지적장애 학생 집단과 언어연령을 일치시킨 일반 아동 집단 의 높임법 이해 능력에 따른 비모수 Kruskal-Wallis 검증을 분 석한 결과, 지적장애 학생들은 연령이 증가하면서 평균과 표준 편차 모두 높아졌으나 그 차이가 유의미하지는 않았다 $\left(\chi^{2}=\right.$ $1.674, p=0.443)$. 언어연령을 일치시킨 일반 아동 집단 역시 언 어연령 10 세 $>12$ 세 > 11세 순으로 점수가 높아졌는데 통계 적으로 유의미한 증가로 보이지는 않는다 $\left(\chi^{2}=1.152, p=0.562\right)$.

Table 2. Comprehension of honorific system method by language age according to nonparametric Kruskal-Wallis test results

\begin{tabular}{ccccccccc}
\hline Group & Age & $\mathrm{n}$ & $\mathrm{M}$ & $\mathrm{SD}$ & $\begin{array}{c}\text { Average- } \\
\text { rank }\end{array}$ & $\chi^{2}$ & $\mathrm{~F}$ & $p$-value \\
\hline TD & $10 \mathrm{~L}-\mathrm{y}$ & 5 & 3.53 & 0.97 & 48.17 & & & \\
& $11 \mathrm{~L}-\mathrm{y}$ & 5 & 3.26 & 1.14 & 41.67 & 1.152 & 2 & 0.562 \\
& $12 \mathrm{~L}-\mathrm{y}$ & 5 & 3.42 & 1.08 & 46.67 & & & \\
IDS & $10 \mathrm{~L}-\mathrm{y}$ & 5 & 2.53 & 1.13 & 42.95 & & & \\
& $11 \mathrm{~L}-\mathrm{y}$ & 5 & 2.60 & 1.20 & 43.18 & 1.674 & 2 & 0.443 \\
& $12 \mathrm{~L}-\mathrm{y}$ & 5 & 2.93 & 1.28 & 50.37 & & & \\
\hline
\end{tabular}

M: mean, SD: standard deviation, TD: typically developing children, IDS: intellectual disability students, L-y: language years old
높임법 유형(주체, 객체, 상대 높임법)에 따른 세 집단의 높임법 이해 능력의 비교

세 집단[ordinary adults $(\mathrm{OA})=15$ 명, $\mathrm{TD}=15$ 명, $\mathrm{IDS}=15$ 명 $]$ 에 따른 높임법 유형(주체, 객체, 상대 높임법) 이해 차이를 분석 한 결과는 Table 3 과 같다.

높임법 유형별 분석에서는 주체높임법과 객체높임법과 상대 높임법 모두에서 세 집단 간의 유의한 차이가 나타났다 $(p<$ 0.001). Duncan 사후 검증 결과 지적장애 학생 집단과 일반 아 동, 일반 성인 집단이 각각 차이가 있었다. 지적장애 학생 집단 은 다른 두 집단에 비해 평균이 가장 낮았다.

Table 3. Mean and SD by 3 groups comprehension for honorific system $(\mathrm{SH}, \mathrm{OH}, \mathrm{HH})$

\begin{tabular}{lccccccc}
\hline Group & $\mathrm{n}$ & $\mathrm{M}$ & $\mathrm{SD}$ & $\mathrm{df}$ & $\mathrm{F}$ & $p$-value & Ducan \\
\hline SH & & & & & & & \\
OA & 15 & 4.00 & 0.00 & & & & IDS $\neq$ \\
TD & 15 & 3.40 & 0.74 & 2 & 13.42 & $0.000^{*}$ & OA \\
IDS & 15 & 2.67 & 0.98 & 42 & & & $\neq \mathrm{TD}$ \\
OH & & & & & & & \\
OA & 15 & 5.73 & 0.46 & 2 & & & IDS $\neq$ \\
TD & 15 & 4.80 & 0.86 & 2 & 14.22 & $0.000^{*}$ & OA \\
IDS & 15 & 4.00 & 1.19 & 42 & & & $\neq$ TD \\
HH & & & & & & & \\
OA & 15 & 1.80 & 0.41 & 2 & & & IDS $\neq$ \\
TD & 15 & 2.00 & 0.00 & 42 & 4.90 & $0.012^{\dagger}$ & TD, \\
IDS & 15 & 1.40 & 0.83 & & & & OA \\
\hline
\end{tabular}

${ }^{*} p<0.01,{ }^{\dagger} p<0.05$. M: mean, SD: standard deviation, SH: subject honorific, $\mathrm{OH}$ : object honorific, $\mathrm{HH}$ : hearer honorific, OA: ordinary adult, TD: typically developing children, IDS: intellectual disability students

Table 4. Mean and SD by 3 groups expression for honorific system question type's level of difficulty

\begin{tabular}{lccccccc}
\hline Group & $\mathrm{n}$ & $\mathrm{M}$ & $\mathrm{SD}$ & $\mathrm{df}$ & $\mathrm{F}$ & $p$-value & Ducan \\
\hline AA & & & & & & & \\
OA & 15 & 3.80 & 0.41 & 2 & & & $\mathrm{IDS} \neq$ \\
TD & 15 & 3.66 & 0.49 & 2 & 15.82 & $0.000^{*}$ & $\mathrm{OA}$ \\
IDS & 15 & 2.47 & 1.22 & 42 & & & $\mathrm{TD}$ \\
A & & & & & & & \\
OA & 15 & 3.80 & 0.41 & 2 & & & IDS, \\
TD & 15 & 3.00 & 1.00 & 42 & 9.80 & $0.000^{*}$ & TD $\neq$ \\
IDS & 15 & 2.60 & 0.74 & & & & OA \\
BA & & & & & & & \\
OA & 15 & 4.00 & 0.00 & 2 & & & IDS $\neq$ \\
TD & 15 & 3.67 & 0.62 & 2 & 10.65 & $0.000^{*}$ & OA, \\
IDS & 15 & 3.00 & 0.85 & 42 & & & TD \\
\hline
\end{tabular}

${ }^{*} p<0.001$. M: mean, SD: standard deviation, AA: above average, A: average, BA: below average, OA: ordinary adult, TD: typically developing children, IDS: intellectual disability students 
높임법 검사 문항 형식 난이도(상, 중, 하)에 따른 세 집단의 높임법 이해 능력의 비교 결과

세 집단 $(\mathrm{OA}=15$ 명, $\mathrm{TD}=15$ 명, $\mathrm{IDS}=15$ 명 $)$ 의 검사 문항 형 식의 난이도 차이에 따른 이해 능력을 분석한 결과는 Table 4 와 같다.

높임법 이해 검사 문항 형식 난이도(상, 중, 하)에 따른 비교 결과 검사 문항 형식 난이도가 낮을수록 모든 집단의 평균이 높은 것으로 나타났으며 검사 문항 형식 난이도가 높을수록 평균이 낮게 나타났다. 높임법 이해 검사 문항 형식 난이도가 '상'인 문항의 점수를 비교한 결과, 일반 성인 집단 평균은 3.80 [standard deviation $(\mathrm{SD})=0.41]$, 일반 아동 집단 평균 $3.66(\mathrm{SD}=0.49)$, 지적장애 학생 집단 평균 $2.47(\mathrm{SD}=1.22)$ 로 일반 성인 > 일반 아동 > 지적장애 학생 집단 순으로 점수가 높았으며 이러한 점수의 차이는 유의미했다 $(p<0.001)$. Duncan 사후 검증 결과 지적장애 학생 집단은 일반 성인 집단, 일 반 아동 집단과 차이가 있었다. 높임법 이해 검사 문항 형식 난 이도가 ‘중’인 문항 점수에서 역시 일반 성인 집단 평균 3.80(SD $=0.41)$, 일반 아동 집단 평균 $3.00(\mathrm{SD}=1.00)$, 지적장애 학생 집 단 평균 2.60(SD = 0.74)으로 일반 성인 $>$ 일반 아동 $>$ 지적장 애 학생 집단 순으로 나타났으며 이들 간의 차이는 통계적으로 유의미했다 $(p<0.001)$. Duncan 사후 검증 결과 지적장애 학생 집단은 일반 아동 집단 및 일반 성인 집단과 차이가 있었다. 또 한 높임법 이해 검사 문항 형식 난이도가 ‘하인 경우 일반 성인 집단 평균 $4.00(\mathrm{SD}=0.00)$, 일반 아동 집단 평균 $3.67(\mathrm{SD}=$ $0.62)$, 지적장애 학생 집단 평균 $3.00(\mathrm{SD}=0.85)$ 으로 일반 성인 $>$ 일반 아동 > 지적장애 학생 순이었으며 세 집단 간 유의미 한 차이가 있는 것으로 나타났다.

\section{높임법 표현 능력 검사 결과}

두 집단(지적장애 학생 집단과 언어연령을 일치시킨 일반 아동 집단)의 언어연령(10세, 11세, 12세)에 따른 높임법 표현 결과

언어연령 10 세 $(\mathrm{TD}=5$ 명, $\mathrm{IDS}=5$ 명 $), 11$ 세 $(\mathrm{TD}=5$ 명, $\mathrm{IDS}=$

Table 5. Expression of honorific system method by language age according to nonparametric Kruskal-Wallis test results

\begin{tabular}{lcccccccc}
\hline Group & Age & $\mathrm{n}$ & $\mathrm{M}$ & $\mathrm{SD}$ & $\begin{array}{c}\text { Average } \\
\text {-rank }\end{array}$ & $\chi^{2}$ & $\mathrm{~F}$ & $p$-value \\
\hline TD & $10 \mathrm{~L}-\mathrm{y}$ & 5 & 3.67 & 1.40 & 43.37 & & & \\
& $11 \mathrm{~L}-\mathrm{y}$ & 5 & 3.43 & 1.41 & 44.45 & 0.728 & 2 & 0.695 \\
& $12 \mathrm{~L}-\mathrm{y}$ & 5 & 3.70 & 1.47 & 48.68 & & & \\
IDS & $10 \mathrm{~L}-\mathrm{y}$ & 5 & 2.10 & 1.04 & 32.65 & & & \\
& $11 \mathrm{~L}-\mathrm{y}$ & 5 & 3.00 & 1.37 & 51.28 & 11.494 & 2 & $0.003^{*}$ \\
& $12 \mathrm{~L}-\mathrm{y}$ & 5 & 3.17 & 1.41 & 52.57 & & & \\
\hline
\end{tabular}

${ }^{*} p<0.01$. M: mean, SD: standard deviation, TD: typically developing children, IDS: intellectual disability students, L-y: language years old
5 명), 12 세 $(\mathrm{TD}=5$ 명, IDS = 5명)의 높임법 표현 능력을 검사한 결과는 Table 5 와 같다.

지적장애 학생 집단과 언어연령을 일치시킨 일반 아동 집단 의 높임법 표현 능력에 따른 비모수 Kruskal-Wallis 검증을 분 석한 결과, 지적장애 학생 집단은 연령이 증가하면서 평균이 모 두 증가하는 모습을 보였으며 통계적으로 유의미한 결과를 나 타내었다 $\left(\chi^{2}=11.494, p<0.01\right)$. 언어연령을 일치시킨 일반 아 동 집단의 경우 언어연령 12 세 > 10 세 > 11세 순으로 표현 점 수가 나타났지만 이 세 집단의 차이는 통계적으로 유의미한 결 과는 아니었다 $\left(\chi^{2}=0.728, p=0.695\right)$.

\section{높임법 유형(주체, 객체, 상대 높임법)에 따른 세 집단의} 높임법 표현 능력의 비교

세 집단 $(\mathrm{OA}=15$ 명, $\mathrm{TD}=15$ 명, $\mathrm{IDS}=15$ 명 $)$ 에 따른 높임법 유형(주체, 객체, 상대 높임법) 표현 차이를 분석한 결과는 $\mathrm{Ta}-$ ble 6 과 같다.

주체높임법 표현 점수는 일반 성인 집단 평균 5.47( $\mathrm{SD}=0.63)$, 일반 아동 집단 평균 $4.87(\mathrm{SD}=0.99)$, 지적장애 학생 집단 평 균 3.40(SD = 1.45)으로 일반 성인 > 일반 아동 > 지적장애 학 생 집단 순이었으며 세 집단 간에 유의미한 차이가 있었다 $(p<$ 0.001). Duncan 사후 검증 결과 세 집단 각각에서 차이를 나타 냈다. 객체높임법 표현 점수는 일반 성인 집단 평균 $6.20(\mathrm{SD}=$ $0.77)$, 일반 아동 집단 평균 $5.47(\mathrm{SD}=0.99)$, 지적장애 학생 집 단 평균 4.27( $\mathrm{SD}=1.62)$ 로 일반 성인 $>$ 일반 아동 > 지적장 애 학생 집단 순으로 나타났으며 $(p<0.001)$, Duncan 사후 검 증 결과 지적장애 학생과 일반 성인 집단, 일반 아동 집단이 서 로 다른 집단으로 나타났다. 상대높임법 표현 점수의 경우 일반

Table 6. Mean and SD by 3 groups expression for honorific system (SH, OH, $\mathrm{HH})$

\begin{tabular}{lccccccc}
\hline Group & $\mathrm{n}$ & $\mathrm{M}$ & $\mathrm{SD}$ & $\mathrm{df}$ & $\mathrm{F}$ & $p$-value & Ducan \\
\hline SH & & & & & & & \\
OA & 15 & 5.47 & 0.63 & & & & IDS $\neq$ \\
TD & 15 & 4.87 & 0.99 & 2 & 14.51 & $0.000^{*}$ & $\mathrm{OA}$ \\
IDS & 15 & 3.40 & 1.45 & 42 & & & TD \\
OH & & & & & & & \\
OA & 15 & 6.20 & 0.77 & 2 & & & IDS $\neq$ \\
TD & 15 & 5.47 & 0.99 & 2 & 10.10 & $0.000^{*}$ & OA, \\
IDS & 15 & 4.27 & 1.62 & 42 & & & TD \\
HH & & & & & & & \\
OA & 15 & 2.87 & 0.35 & & & & IDS $\neq$ \\
TD & 15 & 2.33 & 0.49 & 2 & 15.63 & $0.000^{*}$ & TD \\
IDS & 15 & 1.80 & 0.68 & 42 & & & $\neq$ OA \\
\hline
\end{tabular}

${ }^{*} p<0.001$. M: mean, SD: standard deviation, SH: subject honorific, $\mathrm{OH}$ : object honorific, $\mathrm{HH}$ : hearer honorific, $\mathrm{OA}$ : ordinary adult, TD: typically developing children, IDS: intellectual disability students 
성인 집단 평균 $2.87(\mathrm{SD}=0.35)$, 일반 아동 집단 평균 $2.33(\mathrm{SD}=$ $0.49)$, 지적장애 학생 집단 평균 $1.80(\mathrm{SD}=0.68)$ 으로 일반 성인 $>$ 일반 아동 > 지적장애 학생 집단 순으로 유의미한 차이가 있는 것으로 나타났으며 $(p<0.001)$, Duncan 사후 검증 결과 세 집단이 서로 다른 집단으로 나타났다.

높임법 검사 문항 형식 난이도(상, 중, 하)에 따른 세 집단의 높임법 표현 능력의 비교 결과

세 집단 $(\mathrm{OA}=15$ 명, $\mathrm{TD}=15$ 명, $\mathrm{IDS}=15$ 명 $)$ 의 검사 문항 형 식의 난이도 차이에 따른 표현 능력을 분석한 결과는 Table 7과 같다.

높임법 표현의 검사 문항 형식 난이도에 따라서 세 집단을 비교한 결과 모든 집단에서 하 > 중 > 상의 순으로 평균이 높 게 나타났다. 높임법 표현 검사 문항 형식 난이도 '상' 비교 결과 일반 성인 집단 평균은 $3.20(\mathrm{SD}=0.56)$, 일반 아동 집단 평균

Table 7. Mean and SD by 3 groups expression for honorific system question type's level of difficulty

\begin{tabular}{crrrrrrr}
\hline Group & $\mathrm{n}$ & $\mathrm{M}$ & $\mathrm{SD}$ & $\mathrm{df}$ & $\mathrm{F}$ & $p$-value & Ducan \\
\hline AA & & & & & & & \\
OA & 15 & 3.20 & 0.56 & 2 & & & IDS $\neq$ \\
TD & 15 & 2.60 & 0.51 & 2 & 20.47 & $0.000^{*}$ & $\mathrm{TD} \neq$ \\
IDS & 15 & 1.87 & 0.64 & & & & OA \\
A & & & & & & & \\
OA & 15 & 3.54 & 0.52 & 2 & & & IDS, \\
TD & 15 & 2.73 & 0.96 & 2 & 10.22 & $0.000^{*}$ & TD $\neq$ \\
IDS & 15 & 2.13 & 0.99 & 42 & & & OA \\
BA & & & & & & & \\
OA & 15 & 4.00 & 0.00 & 2 & & & IDS, \\
TD & 15 & 3.60 & 0.51 & 42 & 5.49 & $0.008^{*}$ & TD $\neq$ TD, \\
IDS & 15 & 3.22 & 0.82 & & & & OA \\
\hline
\end{tabular}

${ }^{*} p<0.001$. M: mean, SD: standard deviation, AA: above average, A: average, BA: below average, OA: ordinary adult, TD: typically developing children, IDS: intellectual disability students
2.60(SD $=0.51)$, 지적장애 학생 집단 평균 $1.87(\mathrm{SD}=0.64)$ 로 일반 성인 > 일반 아동 > 지적장애 학생 집단 순이었으며 세 집단 간 유의한 차이가 있는 것으로 나타났다 $(p<0.001)$. 높임 법 표현 검사 문항 형식 난이도 ‘중' 비교 결과 일반 성인 집단 평균 3.54(SD = 0.52), 일반 아동 집단 평균 2.73( $\mathrm{SD}=0.96)$, 지 적장애 학생 집단 평균 2.13(SD = 0.99)으로 일반 성인 > 일반 아동 > 지적장애 학생 집단 순이었으며 세 집단 간의 차이는 유의했다 $(p<0.001)$. Duncan 사후 검증 결과 지적장애 성인 집단, 일반 아동 집단과 일반 성인 집단이 다른 집단으로 나타 났다. 높임법 표현 검사 문항 형식 난이도 ‘하' 비교 결과 일반 성인 집단 평균 4.00(SD $=0.00)$, 일반 초등학생 집단 평균 $3.60(\mathrm{SD}=0.51)$, 지적장애 학생 집단 평균 $3.22(\mathrm{SD}=0.82)$ 로 일 반 성인 $>$ 일반 아동 $>$ 지적장애 학생 집단 순으로 점수가 나 타났으며 세 집단 간에 유의한 차이가 있었다 $(p<0.001)$. Duncan 사후 검증 결과 지적장애 성인 집단과 일반 아동 집단, 그리 고 일반 아동 집단과 일반 성인 집단이 다른 집단으로 나타났다.

\section{높임법 문항 오류 유형 분석}

\section{지적장애 학생 집단의 높임법 이해 문항(1 12번)별 오류 유형 분석결과}

지적장애 학생 집단의 높임법 이해 검사에 대한 문항별 오류 반응과 높임법 유형에 따른 오류 반응을 분석한 결과는 Figure 2,3 과 같다.

가장 높은 오류 반응을 보인 문항은 12 번으로 높임법이 틀린 표현을 고르는 문항이며, 다음으로 높은 오류 반응을 보인 문 항은 10 번으로 높임법이 잘못된 문장을 고르는 문항이다(Appendix 3).

12 번 문항의 경우 지적장애 성인 집단의 대부분 4)번, 다음으 로 10번 문항의 경우, 2) > 1)>3) 순으로 오반응을 나타냈다.

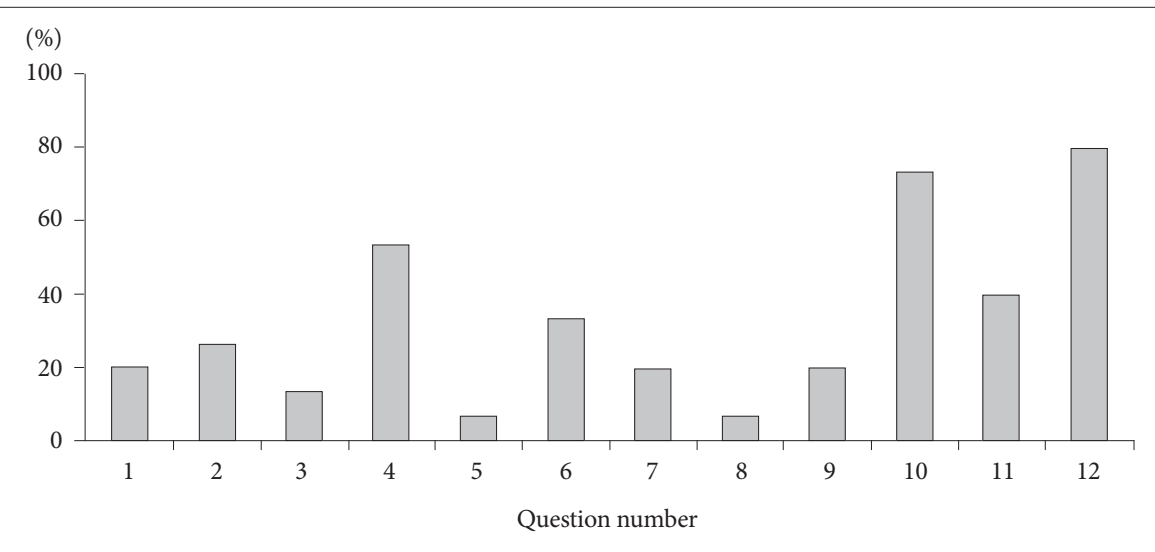

Figure 2. Percentage of error responses by question of honorific comprehension examination. 
지적장애 학생 집단의 높임법 표현 문항(1 12번)별 오류 유형 분석결과

지적장애 학생 집단의 높임법 표현 검사에 대한 문항별 오류 반응과 높임법 유형에 따른 오류 반응을 분석한 결과는 Figure 4,5 와 같다.
가장 높은 오류 반응을 보인 문항은 6번, 9번으로 나타났다 (Appendix 4).

6번 문항의 경우 대부분의 지적장애 학생 집단에서 '찾아준' 에 높임 선어말어미 '-시-' 사용에 어려움을 보였으며, 또한 9번 문항의 경우 다른 나라 사람에게 우리나라를 이야기할 때 '저
Figure 3. Percentage of error responses by honorific system $(\mathrm{SH}, \mathrm{OH}, \mathrm{HH}$ ) of honorific comprehension examination. $\mathrm{SH}$ : subject honorific, $\mathrm{OH}$ : object honorific, $\mathrm{HH}$ : hearer honorific.

Figure 4. Percentage of error responses by question of honorific expressive examination.
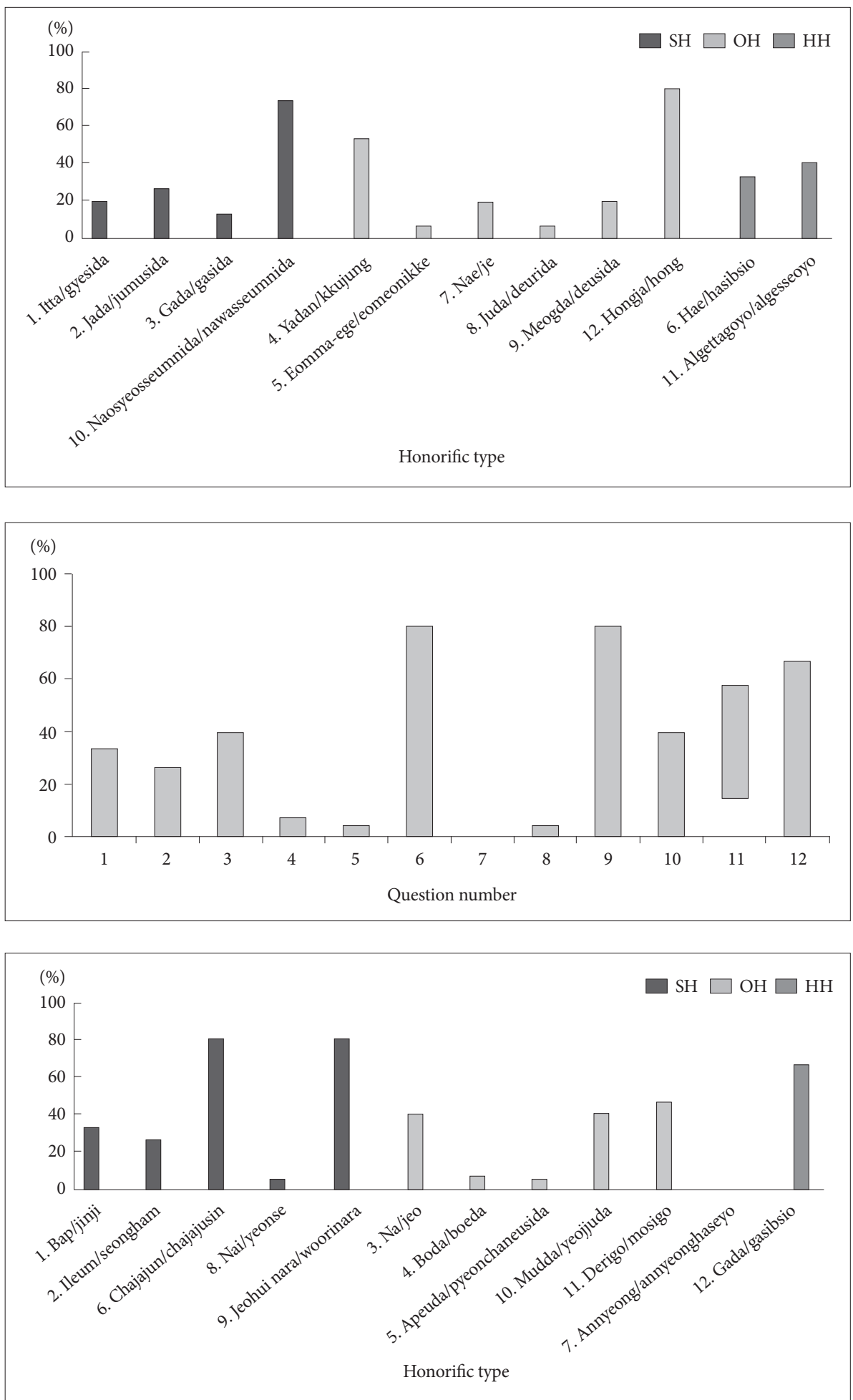

Figure 5. Percentage of error responses by honorific system $(\mathrm{SH}, \mathrm{OH}, \mathrm{HH})$ of honorific expressive examination. $\mathrm{SH}$ : subject honorific, $\mathrm{OH}$ : object honorific, $\mathrm{HH}$ : hearer honorific. 
희 나라’로 낮추어 사용하지 않고 '우리나라'로 표현해야 하나, 대부분 지적장애 학생 집단의 경우 문제점을 발견하지 못하고 그대로 '저희 나라'로 표현하였다.

\section{DISCUSSIONS}

본 연구의 목적은 지적장애 학생과 언어연령을 일치시킨 일 반 아동, 그리고 지적장애 학생과 생활연령을 일치시킨 일반 성 인 간에 높임법 이해·표현 능력의 차이를 살펴봄으로써 높임법 에 대한 교육의 필요성을 확인하고자 하는 것이었다. 이를 위해 세 집단 간에 따른 높임법 유형(주체, 객체, 상대 높임법) 및 검 사 문항 형식 난이도(상, 중, 하)에 따른 이해·표현 능력 차이와 이해·표현 문항 오류 반응에 대한 분석을 실시하였다. 이에 대 한 결론 및 논의 내용은 다음과 같다.

첫째, 높임법 이해 검사를 통해 연령에 따른 높임법 이해 능 력의 차이를 분석한 결과, 지적장애 학생 집단은 언어연령이 동 일한 일반 아동 집단과 비교하여 평균이 낮은 것으로 나타났 다. 그럼에도 불구하고 지적장애 학생 집단은 10세, 11세, 12세 로 언어 연령이 높아짐에 따라 높임법 점수의 평균치가 증가하 는 것을 보여주었다. $\mathrm{Chu}(2005)$ 에 따르면 문화-가족성 지적장 애를 보이는 사람들의 인지 과정과 발달은 정상적인 사람들과 비교해 질적 유사성이 있으며, 차이점이 있다면 인지 발달의 속 도와 지식을 획득하는 인지기능의 수준임을 밝혔다. 이러한 결 과는 지적장애 학생 집단의 언어연령이 발달함에 따라 높임법 을 사용하는 능력이 발달하며 이는 높임법 이해 교육이 지속적 으로 필요함을 시사하는 것이다.

한편 높임법 이해 검사에서 높임법 유형(주체, 객체, 상대 높 임법)에 따른 세 집단의 차이를 살펴본 결과 주체높임법, 객체 높임법 그리고 상대높임법 모두에서 지적장애 학생 집단이 다 른 두 집단에 비해 평균이 낮게 나타났다. 또한 이해과제에서 상대높임법 문항의 수는 주체높임법과 객체높임법에 비해 적었 다. Yoon(2016)에 따르면 과거에는 '하오'체와 '하게'체가 두루 사용되는 종결 표현이었으나 현재에는 과거에 비해 그 쓰임이 축소되었기 때문에 높임법의 교육 내용에도 이를 반영할 필요 가 있음을 주장한다. 이 연구에서는 실제 언어생활을 반영한 상대 높임의 체계를 높임 표현[+높임]인 '하십시오'체, '해요'체, 낮춤 표현[-높임]인 '해라'체, '해’체로 제시하고 있다. 본 연구에 서도 상대높임법 문항 수를 제한하여 제시하였다. 주체, 객체, 상대 높임법 이해에 대한 문항당 평균을 살펴보면 주체높임법 의 경우 일반 성인 집단은 정반응 $100 \%$ 로 1.00 이었으며, 일반 아동 집단 0.85 , 지적장애 학생 집단 0.67 로 나타났다. 객체높임 법은 일반 성인 집단 0.96 , 일반 아동 집단 0.80 , 지적장애 학생 집단 0.67 로 나타났다. 상대높임법의 경우 일반 성인 집단 0.90 ,
일반 아동 집단 정반응 $100 \%$ 로 1.00 , 지적장애 학생 집단 0.70 으로 나타났다. 본 연구의 대상이었던 지적장애 학생들은 주체 높임법, 객체높임법 그리고 상대높임법의 세 유형 모두에서 낮 았으며 이러한 결과는 지적장애인의 사회적 의사소통을 위한 높임법 교육의 필요성을 알리는 것이라고 볼 수 있다. 한편 상 대높임법에서는 세 집단 모두 다른 유형의 높임법에 비해 평균 점수가 높았다. 이러한 결과는 상대높임법이 국어의 높임법 중 에서 가장 발달되어 있으며 이는 청자와 서로 대면하고 있는 상태의 높임법이기 때문이라는 연구를 지지하는 것이다(Choi, 2008; Min, 1999). 따라서 지적장애 학생 집단의 높임법 이해 교육에서는 유형을 고려하여 먼저 상대높임법을 지도해야 할 것이라는 시사점을 준다.

높임법 이해 검사에서 높임법 검사 문항 형식 난이도(상, 중, 하)에 따른 세 집단 분석결과에서는 세 집단 모두 검사 문항 형 식의 난이도가 낮을수록 평균이 높았으며 검사 문항 형식의 난 이도가 높을수록 평균이 낮게 나타났다. 또한 세 집단의 평균 을 비교했을 때, 검사 문항 형식의 난이도 상, 중, 하 모두에서 지적장애 학생 집단의 평균이 가장 낮게 나타났다. 이러한 결 과는 지적장애 학생 집단의 높임법 이해를 위한 평가 시, 검사 문항 형식의 난이도를 고려해야 할 필요성을 시사해 준다.

둘째, 높임법 표현 검사 후 연령에 따른 높임법 표현 능력의 차이를 분석한 결과 지적장애 학생 집단은 언어연령이 동일한 일반 아동 집단과 비교하여 평균이 낮은 것으로 나타났다. 특 히 통계적으로 언어언령이 10 세인 지적장애 집단과 일반 아동 의 평균이 가장 많은 차이를 보였다. 10세에서 높임법 표현에 가장 큰 차이를 보이는 이유는 초등학교 교육 과정에 따르면 초등학교 3 4학년 문법 영역에 ‘높임법을 알고 언어 예절에 맞 게 사용한다.라고 목표를 명시하고 있는 것에서 찾을 수 있겠 다(Ministry of Education, 2015). 교육 과정을 통해 배우고 있 는 언어연령 10 세인 일반 아동 집단과 지적장애 학생 집단 간 의 통계적으로 유의미한 차이가 나타난 것은 당연한 결과라는 생각을 하게 된다. 또한 언어연령 10 세인 지적장애 학생 집단과 11 세, 12 세인 지적장애 학생 집단 간에 통계적으로 유의미한 차이가 나타났다. 피아제는 진정한 의미의 상징적이고 추상적 인 사고 양식은 형식적 조작 단계(formal operational stage: 11 세 이상)에서 획득된다고 한다. 11 세 이상 연령의 아동은 더 이 상 실재에 의존함으로써 방해받는 일 없이 추상적인 것을 다룰 수 있으며, 가역적 사고가 더 융통성 있게 이루어진다고 하였 다. 이는 대인관계나 다양한 상황에서의 대화 시 규범에 맞는 높임법을 사용하는 능력이 함께 발달되어야 함을 의미하며, 이 러한 발달은 학령기의 유추 능력과도 연관되어 있다고 할 수 있겠다. 이 논의는 언어연령 10 세 이전부터 지적장애 학생 집단 의 높임법 표현 교육의 필요성을 시사해 준다. 
높임법 표현 검사 결과 높임법 유형(주체, 객체, 상대 높임법) 에 따른 세 집단 분석에서는 주체높임법, 객체높임법, 상대높임 법 표현 점수는 모두 일반 성인, 일반 아동, 지적장애 학생 집단 순이었으며 세 집단 간에 유의미한 차이가 나타났다. 앞서 이해 검사와 마찬가지로 표현 검사에서도 동일하게 상대높임법 문항 수를 제한하였다. 문항당 평균치를 살펴보면 주체높임법의 경 우 일반 성인 집단 0.91 , 일반 아동 집단 0.81 , 지적장애 학생 집 단 0.57 로 나타났다, 객체높임법의 경우 일반 성인 집단 0.89 , 일반 아동 집단 0.78 , 지적장애 학생 집단 0.61 로 나타났다. 상 대높임법의 경우 일반 성인 집단 0.96 , 일반 아동 집단 0.78 , 지 적장애 학생 집단 0.60 으로 나타났다. 지적장애 학생들은 주체, 객체, 상대 높임법 표현 모두에서 일반 성인 및 일반 아동과 비 교하여 가장 낮은 평균을 보였다. 객체높임법에서는 가장 높은 점수를, 주제높임법에서 가장 낮은 점수를 나타냈다. 본 연구의 결과는 지적장애 학생들이 객체높임법보다 주체높임법을 습득 하는 데 어려움을 느끼는 이유가 주체 높임에서 보다 복잡한 문법 구조가 요구되기 때문이라는 Lee \& Heo(2015)의 연구결 과와 일치하였다. 또한 이러한 결과는 결국 지적장애 성인 집단 의 높임법 표현 교육 시 객체높임법 지도가 우선 중재되는 것 이 효과적임을 시사해 준다. 또한 높임법 표현 검사에서 높임법 검사 문항 형식 난이도(상, 중, 하)에 따른 세 집단 분석 결과 상, 중, 하 표현 결과 모두 집단 평균이 일반 성인 > 일반 아동 $>$ 지적장애 학생 집단 순으로 유의미한 차이가 나타났다. 이 러한 결과는 앞서 이해 검사와 마찬가지로 검사 문항 형식 난 이도를 고려한 평가의 필요성을 시사해 준다.

셋째, 높임법 오류 유형 분석결과 지적장애 학생의 높임법 이 해 문항별 오류 반응에서는 이름을 높여 부르는 문항과 일상생 활에서 높임법을 사용하는 문장에서 가장 높은 오류를 보였으 며, 언어연령을 일치시킨 일반 아동 집단은 〈4번: 야단 $\rightarrow$ 꾸중〉 문항에서 가장 높은 오류율이 나타났으며, 다음으로 높은 반 응을 보인 오류율은 지적장애 학생 집단과 동일하게 이름을 높 여 부르는 문항에서 높은 오류율이 나타났다. 이러한 결과는 초 등학교 3학년 이상 학생들을 대상으로 조사한 연구에서 이름 높이기, 일상생활 높임법을 올바르게 사용하고 있는 학생이 $27 \%$ 에 불과하였다는 $\operatorname{Kim}(2009)$ 의 결과가 본 연구를 뒷받침 해 준다. 10 번 문항에서 '음식'은 간접 높임의 대상이 아니므로 높여서 표현할 수 없으며, 불필요한 '-시-를 넣은 표현을 적지 않게 사용하고 있다는 연구 결과와도 일치하였다(National Institute of Korean Language, 2011).

지적장애 학생 집단의 높임법 표현 문항별 오류 반응 분석 결과 〈6번: 찾아준 $\rightarrow$ 찾아주신〉, 〈9번: 저희 나라 $\rightarrow$ 우리나라〉 문항에서 가장 높은 오류율이 나타났다. 즉 높임 선어말어미 '-시-'와 ‘저희/우리' 표현에 가장 높은 오류를 보인 것이다. 또한
언어연령을 일치시킨 일반 아동 집단의 높임법 표현 문항별 오 류 반응에서도 지적장애 학생 집단과 동일하게 6번, 9번 문항 에서 가장 높은 오류를 보였다. 초등학교 4학년, 6학년, 중학교 2학년을 대상으로 일상생활에서 자주 쓰이는 높임 표현의 실 태를 조사한 결과 주체높임법에서 높임 표현의 기본적 요소인 선어말어미 '-시-'의 사용이 미흡하다는 $\operatorname{Kang}(2001)$ 의 연구결 과와 그 맥을 같이한다. 또한 3학년 이상 초등학생들의 일상 언 어생활에 속에서 논란이 되는 여러 높임법 사용에서 '저희/우 리' 표현을 바르게 알고 사용하는 학생들이 적다는 $\operatorname{Kim}(2009)$ 의 설문조사 결과와도 일치한다.

본 연구의 대상이었던 지적장애인은 일반 성인이나 언어연령 이 동일한 아동에 비해 높임법 이해 및 표현 능력이 낮게 나타 났지만, 연령이 증가함에 따라서 높임법 이해 및 표현 능력이 지 속적으로 증가하는 것을 보여주었다. 또한 난이도가 낮은 경우 반응이 높았고 주체 높임보다는 상대 높임과 객체 높임 점수가 높게 나타났으므로 이러한 결과를 고려한 높임법 지도의 방향 을 탐색할 필요가 있다고 사료된다. 후속연구에서는 10 세 이하 를 대상으로 높임법 이해 및 표현 능력에 대한 연구를 제안하 며, 더 많은 대상자를 참여시켜 일반화시킬 필요가 있을 것이다.

중심 단어 : 지적장애 학생·높임법·주체높임법·객체높임법· 상대높임법.

\section{Ethical Statement}

This study's test has started with giving research consent forms to the subjects. They had read and understand the information contained within this consent form and signed. In conclusion this study has progressed with the subjects who signed in the research consent forms.

\section{Acknowledgments}

The authors thank all the students who participate in this study.

\section{Declaration of Conflicting Interests}

There are no conflict of interests.

\section{Funding}

N/A

\section{Author Contributions}

The authors contributed to all aspects of this work. J.L. conceived research hypotheses and designed the experiments to reach the conclusion. W.K. and J.L. provided critical feedback and overall direction and planning. S.L. and H.L. collected and analyzed the data. Also, they interpreted the results together and co-wrote the body of the manuscript. H.L. was responsible for handling revisions of the manuscript and proof reading up to the acceptance of the manuscripts.

\section{ORCID iDs}

Wha Soo Kim

https://orcid.org/0000-0003-4787-4824

$\mathrm{Hu}$ In Lee
https://orcid.org/0000-0002-9098-858X 


\section{REFERENCES}

Choi, M. S. (2008). A Study on the guding method and analyzing the usage of honorific for high school students (Unpublished master's thesis). Kyung Hee University, Seoul.

Choi, S. K. (2001). Teaching of Language Arts for Children with Disorders. (pp.103-105). Gwangju: Korean Speech-Language \& Hearing Association.

Chu. Y. G. (2005). Studies on the personality development of people with mental retardation. Institute of Special Education and Rehabitation Science, Daegu University, 44(1), 63-86.

Eom, Y. J. \& Kim, W. S. (2018). Characteristics and strategies of rejection for long-term intellectual disorder adults and men. Journal of International Society for Multicultural Communication, 2018(11), 34-37.

Kang, K. H. (2001). A study for consciousness about honorific expression of the elementary and junior high school student (Unpublished master's thesis). Gongju National University of Education, Gongju.

Kang, M. R. (2019) A study on learning and teaching the intentional Korean honorific use. The department of Korean language education (Unpublished master's thesis). Incheon National University, Incheon.

Kim, H. S. (2014). A study on analyzing the use and the understanding of honorifics for elementary students: Focused on subject honorific (Unpublished master's thesis). Seoul National University of Education, Seoul.

Kim, S. W. (2009). A Study on the honorific teaching method through analyzing the usage of honorific for elementary students. Major in elementary Koean education graduate school of education (Unpublished master's thesis). Busan National University of Education, Busan.

Kim, W. S., Choi, Y. S., \& Lee, G. Y. (2015). Topic maintenance ability of student with mild intellectual disabilities. Journal of Intellectual Disabilities, 17(2), 415-432.

Kim, W. S., Eom, Y. J., \& Lee, G. Y. (2017). A study on the communication of students with mild intellectual disability seen in speech acts. Journal of Intellectual Disabilities, 19(2), 99-119.

Kim, Y. T. (2002). Assessment and Treament of Language Disorders in Children. (pp. 88). Seoul: Hakjisa.

Koo, I. W. (2006). Basic Korean Language Dictionary for High School Students. (pp.32). Seoul: Shinwonbook.

Kwon. W. S. (2015). A case study on improvement of sociability for children with intellectual disabilities: Focused on the task-based approach by Sue Jennings (Unpublished master's thesis). Yongin University,
Yongin.

Lee, J. B. (2002). Korean Linguistics and Social Linguistics. (pp.346-347). Seoul: Worin Publishing Co.

Lee, N. Y. \& Heo, Y. S. (2015). Effects of video self-modeling on the honorific system usage in communication contexts of elementary student with intellectual disabilities. Special Education Research, 14(2), 31-55.

Lee, Y. R. (2019). A study on relative honorifics in Korean textbooks used in the universities in Japan and the improvement plan: Focusing on the social relationship (Unpublished master's thesis). The Graduate School of Education Sangmyung University, Seoul.

Min, H. S. (1999). A Study of Korean Grammar. (pp.183). Seoul: Youkrackbooks.

Ministry of Education. (2015, September 23). Elementary School Curriculum (MOE Notice No. 2015-74). Ministry of Education. Retrieved from https://www.moe.go.kr/boardCnts/view.do?boardID $=141 \& l e v=0$ \&statusYN=C\&s=moe\&m $=0404 \&$ opType $=\mathrm{N} \&$ boardSeq $=60747$.

National Institute of Korean Language. (2011) Standard Language Etiquettehonorific. National Institute of Korean Language. Retrieved from https://www.korean.go.kr/front/reportData/reportDataView.do?mn_ id=207\&report_seq=767\&pageIndex=1.

Park, W. J. \& Lee, J. H. (2017). Korean Expressive Activity Book: Conversation to Each Other-Honorific, and Conversation Express. (pp.22-50). Seoul: Gaeamnamu.

Paul, R. \& Courtenay, F. N. (Trans. Kim, W. S., Kim, S. S., Park, S. H., Jung, B. J., Lee, S. K., Lee, E. J., et al.) (2014). Language Disorders from Infancy through Adolescence. (pp.46). Seoul: Pakhaksa.

Suh, J. W., Hyeon, T. J., \& Park, T. B. (2015). What the Hell Do You Say?: Similar Words in Textbooks, Honorific. (pp.12-32). Seoul: Hansol Su-book.

Suh, Y. R. (2019). Analysis of discourse patterns in elementary school Korean textbooks: According to revision of the course of education in 2015 1-4th grade (Unpublished master's thesis). Education Daegu National University of Education, Daegu.

Won, J. H. (2003). A study on analyzing the usage of honorific expression and honorific education for elementary students: Focus om third, fourth, fifth, and sixth-grade elementary students (Unpublished master's thesis). Korea National University of Education, Cheongju.

Yoon, Y. J. (2016). The study for education methods of Korean honorific system (Unpublished master's thesis). Sogang University, Seoul. 
Appendix 1. 이해 문항 예시

상

※ 다음 중 높임말을 잘못 쓴 문장을 고르세요.

1) 어머니, 어디 가세요?

2) 할머니 약은 드셨어요?

3) 할아버지는 연세가 어떻게 되세요?

4) 엄마, 할아버지가 떡 주래요.

중

※ 다음 중 높임말이 틀린 표현을 고르세요.

〈높임법을 써야 하는 상황〉

1) 저는 2) 부모님께 3) 생신 선물로 별로 해 4) 준 것이 없어요.

하

※ 다음 중 높임말을 바르게 한 문장을 고르세요.

〈은행에 가서 은행원에게 통장을 건네주는 상황〉

나: 1) 여기 내 통장이에요.

2) 여기 제 통장이야.

3) 여기 제 통장이에요.

4) 여기 내 통장이야.

Appendix 2. 표현 문항 예시

상

※ 다음 중 틀린 부분을 찾고, 상황에 맞는 높임말을 문장으로 고쳐 쓰세요.

(뮤지컬을 보러 공연장에 온 상황)

안내 방송: 오늘도 공연장을 찾아준 관객 여러분께 감사의 말씀드립니다.

\section{중}

※ 다음 중 밑줄 친 표현에서 높임말이 틀린 번호를 찾아 바르게 고쳐 쓰세요.

(친구랑 길을 잃어버렸는데, 마침 경찰 아저씨가 지나가는 상황)

친구: 우리 길을 잃어버렸어, 어! 마침 경찰 아저씨가 지나가시네.

나: 1) 내가 2) 경찰 아저씨께 3) 물어보고 4) 올게.

하

※ 다음 중 밑줄 친 표현을 알맞은 높임말로 고쳐 쓰세요.

(태권도 사범님께 전화하는 상황) 안녕? 저 수연이에요. 
Appendix 3. 높임법 이해 12번, 10번 문항

QUESTION 12. 1) 홍자 2) 길자 3) 동자 4) 쓰십니다.

QUESTION 10. 1) 애들아, 선생님 오신다.

2) 재킷 한번 입어 보세요.

3) 영수증 주세요.

4) 주문하신 음식 나오셨습니다.

\section{Appendix 4. 높임법 표현 6번, 9번 문항}

QUESTION 6. 오늘도 공연장을 찾아준 관객 여러분께 감사의 말씀드립니다. $\rightarrow$ 찾아주신

QUESTION 9. 저희 나라는 참 아릅답습니다.

$\rightarrow$ 우리나라 